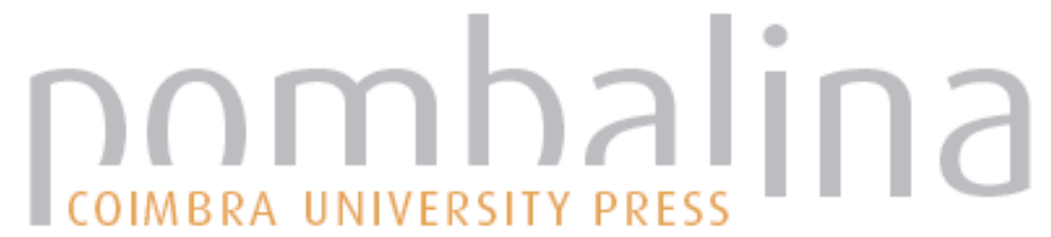

(8)

\section{A bi-regional (rectangular) Input-Output model for Portugal: centro and rest of the country}

\author{
Autor(es): \\ Ramos, Pedro; Cruz, Luís; Barata, Eduardo; Parreiral, André; Ferreira, \\ João-Pedro
}

Publicado por: Imprensa da Universidade de Coimbra

URL persistente:

URI:http://hdl.handle.net/10316.2/38158

DOI:

DOl:http://dx.doi.org/10.14195/978-989-26-1039-9_12

Accessed : $\quad$ 26-Apr-2023 12:18:45

A navegação consulta e descarregamento dos títulos inseridos nas Bibliotecas Digitais UC Digitalis, UC Pombalina e UC Impactum, pressupõem a aceitação plena e sem reservas dos Termos e Condições de Uso destas Bibliotecas Digitais, disponíveis em https://digitalis.uc.pt/pt-pt/termos.

Conforme exposto nos referidos Termos e Condições de Uso, o descarregamento de títulos de acesso restrito requer uma licença válida de autorização devendo o utilizador aceder ao(s) documento(s) a partir de um endereço de IP da instituição detentora da supramencionada licença.

Ao utilizador é apenas permitido o descarregamento para uso pessoal, pelo que o emprego do(s) título(s) descarregado(s) para outro fim, designadamente comercial, carece de autorização do respetivo autor ou editor da obra.

Na medida em que todas as obras da UC Digitalis se encontram protegidas pelo Código do Direito de Autor e Direitos Conexos e demais legislação aplicável, toda a cópia, parcial ou total, deste documento, nos casos em que é legalmente admitida, deverá conter ou fazer-se acompanhar por este aviso. 
IMPRENSA DA UNIVERSIDADE DE COIMBRA

COIMBRA UNIVERSITY PRESS

\section{ASSESSMENT \\ METHODOLOGIES}

ENERGY, MOBILITY AND OTHER

REAL WORLD APPLICATION

\section{PEDRO GODINHO \\ JOANA DIAS}

EDITORS

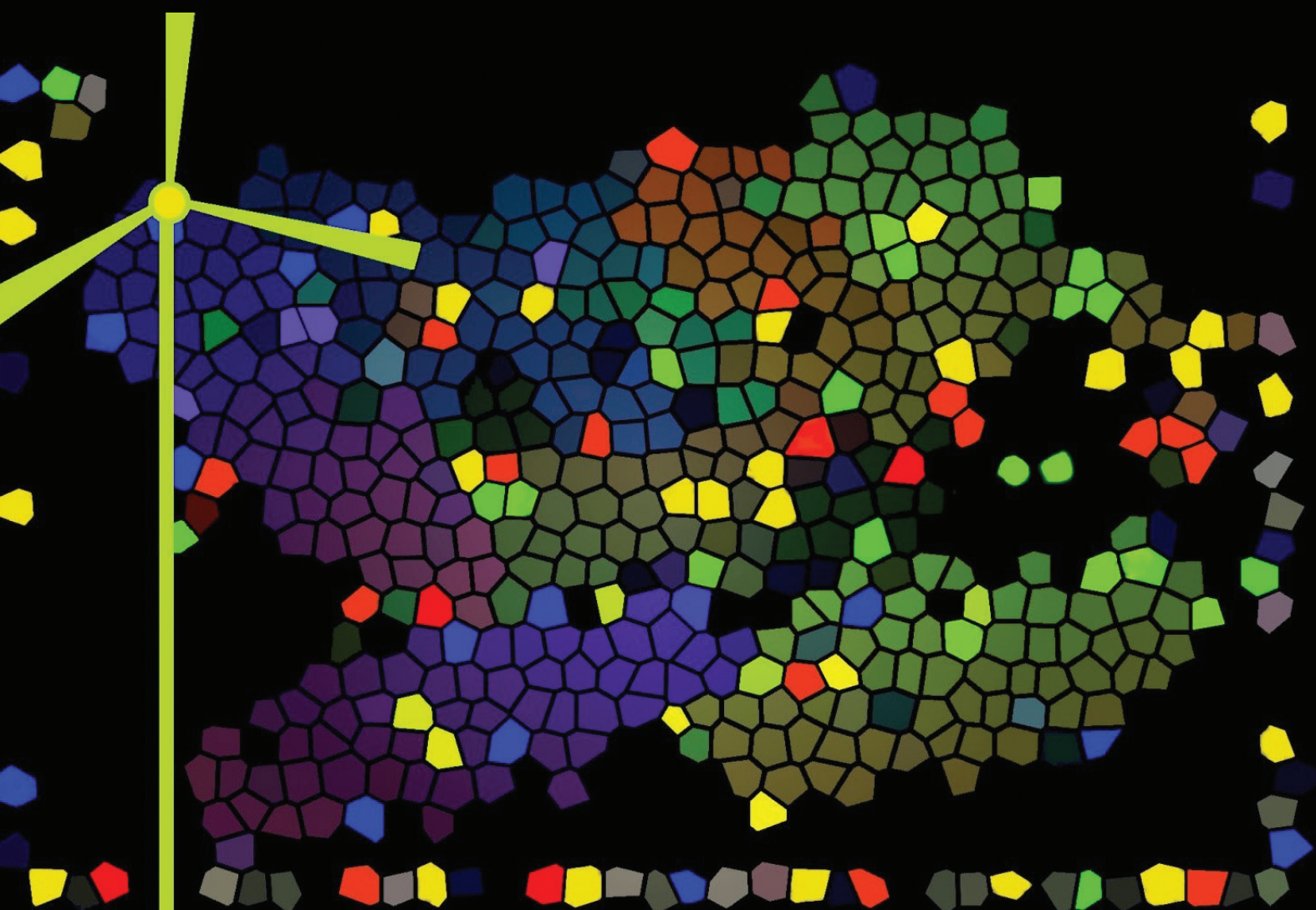




\title{
A BI-REGIONAL（RECTANGULAR） INPUT-OUTPUT MODEL FOR PORTUGAL: CENTRO AND REST OF THE COUNTRY
}

\author{
Pedro Ramos $^{1}$, Luís Cruz ${ }^{1}$, Eduardo Barata ${ }^{1}$, André Parreiral $^{2}$ \\ and João-Pedro Ferreira ${ }^{1}$
}

\begin{abstract}
Regional Input-Output models aim to quantify the impacts on industry's outputs, and other economic indicators, of different final demand vectors for goods and services produced in the same or in different regions. These models are well suited for regional economic analysis as they combine inter-industrial and interregional economic interdependencies. MULTI2C is a general flexible procedure, developed by a group of researchers from the University of Coimbra, Portugal, that allows for the construction of that kind of models for different geographic configurations.

This work explores the construction of a bi-regional input-output model for Portugal, based on the MULTI2C approach, considering two regions: the NUT II Centro of Portugal and the Rest of the Country. This model considers rectangular matrices with 431 products and 134 industries. Further, it considers different types of households according to their main source of income, i.e., labour earnings, capital income, real estate income, retirement benefits and other social transfers. This modelling framework may be closed with respect to the consumption of different household's types, but this paper considers as endogenous the labour earnings type. Besides the model structure and the methodological choices for its construction, this work focuses on estimating interregional trade.
\end{abstract}

\footnotetext{
${ }^{1}$ University of Coimbra, Faculty of Economics

2 Energy for Sustainability - University of Coimbra, Faculty of Economics

E-mails: pnramos@fe.uc.pt, lmgcruz@fe.uc.pt, ebarata@fe.uc.pt, acruzparreiral@fe.uc. pt, joao.ferreira@fe.uc.pt
} 
Finally, the model is used to assess the impacts in the Centro region of Portugal, and in the Rest of the Country, derived from a shift in income's distribution in the Centro region, consisting in a reduction of the labour share, compensated by an increase in business investment, which however do not confine to the NUT II Centro of Portugal but, into some extent, spillover to the Rest of the Country.

Keywords: Input-Output Models; Household Income; Regional Economics.

\section{Introduction}

Regional Input-Output models aim to quantify the impacts on industry's outputs, and other economic indicators, of different final demand vectors for goods and services produced in the same or in different regions. These models are well suited for regional economic analysis as they combine inter-industrial and interregional economic interdependencies.

The initial purpose of this work is to build an input-output model for the Centro region $(C)$, Portugal. This model uses 2010 data and analyses the interactions between the Centro region and the rest of Portugal, hereafter designated as "Rest of the Country" $(R C)$. The Centro region is a NUT II located in mainland Portugal, occupying the central part of its territory (between Lisbon and Oporto) and corresponding to $31 \%$ (28 $405 \mathrm{Km}^{2}$ ) of the country's total area. This region has 2.3 millions of residents (22\% of the country's total) and its GDP represents about $18.5 \%$ of the Portuguese GDP. Next, the bi-regional Centro-Rest of the Country input-output model is explored to assess the impacts in both regions, derived from a shift in the income's distribution in the Centro region, consisting in a reduction of the labour share in this region, compensated by an increase in business investment.

According to the scope and objectives considered, the analysis is organized as follows. Section 2 presents, in sub-section 2.1, the structure of the bi-regional Centro - Rest of the Country input-output model and the main topics considered to build it up; in sub-section 2.2 are explained the main procedures regarding the consideration of different household 
types, according to their main source of income; sub-section 2.3 proposes a discussion on the estimation of the inter-regional trade between the two regions. Section 3 presents an application of the model to assess the impacts in the Centro region, and in the Rest of the Country, derived from a shift in the income's distribution in the Centro region. Section 4 concludes.

\section{The Modelling framework}

The bi-regional input-output model proposed in this work is an application of the MULTI2C (multi-sectoral multi-regional Coimbra model) framework. MULTI2C is a general flexible approach, developed by a group of researchers, mainly from the University of Coimbra (Portugal) that allows for the construction of input-output tables for different geographic configurations ${ }^{3}$. The MULTI2C approach has a great level of detail concerning both the products (or groups of products) included and the industries that produce them. The bi-regional Centro-Rest of the Country input-output model uses 2010 data and is focused on the Portuguese NUT II Centro region. Accordingly, this model considers that the 431 products included in the MULTI2C approach are produced by the 134 industries in the two different regions or are being internationally imported, i.e., part of these products are produced outside the Portuguese territory.

\subsection{The structure of the bi-regional Centro-Rest of the Country input- output model}

The structure of the multi-sector bi-regional Centro-Rest of the Country input-output model is schematically represented in Table 1.

${ }^{3}$ As a rule, MULTI2C models are of the bi-regional kind, as the one used here, although multi-regional structures are also considered. Sargento et al. (2013) have already adopted a similar framework, dividing Portugal in the "interior" and the "coast" parts of the country. The interior-coast dichotomy is again considered in Ramos et. al (2014). For an example of a tri-regional application please see Ferreira et al. (2014). 
Table 1: Structure of the multi-sector bi-regional C-RC input-output model

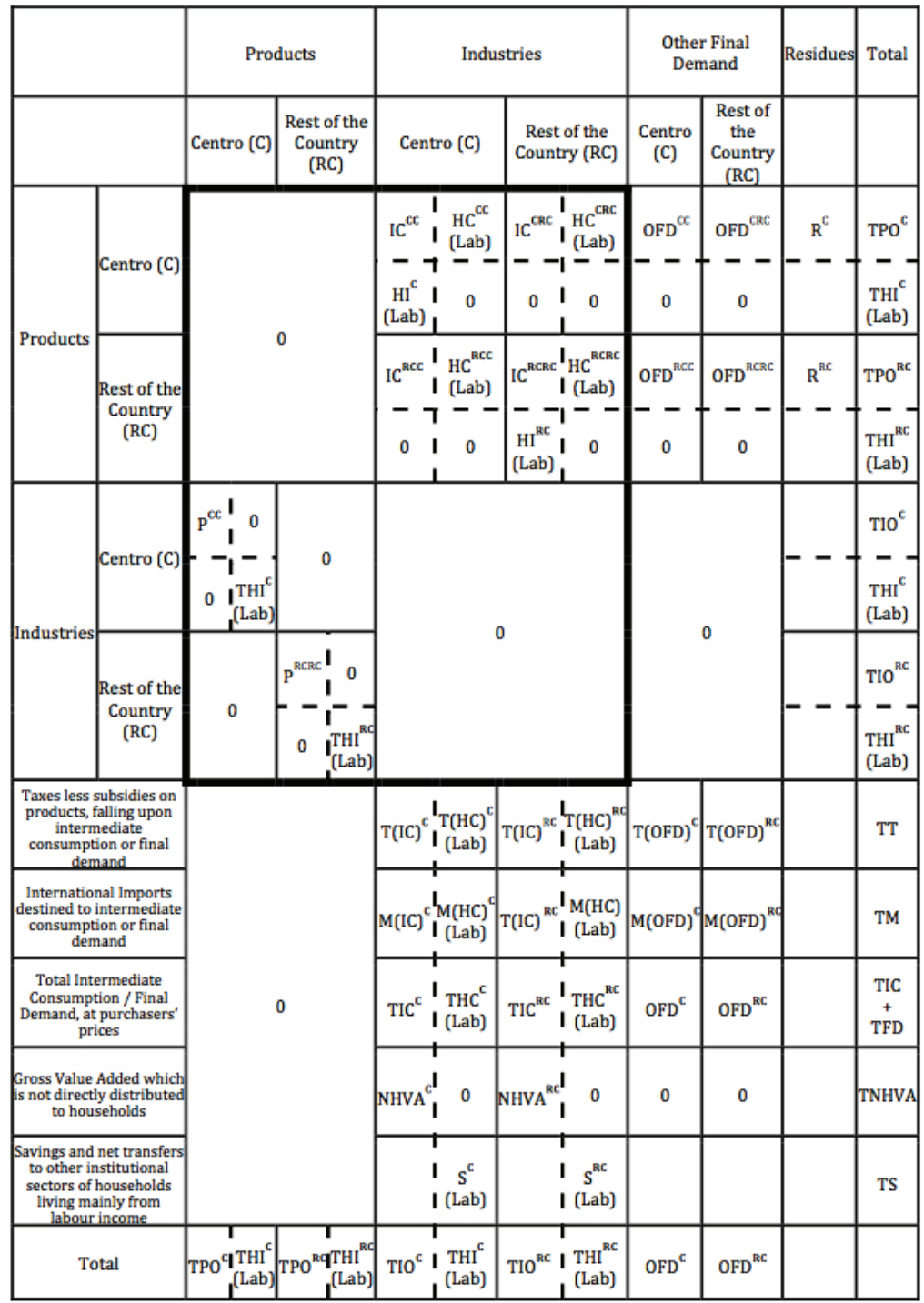

\section{Legend:}

\section{C - Centro}

RC - Rest of the Country

IC ij $^{\mathrm{ij}} \quad i, j=C, R C$ - Intermediate consumption of i's regional products, used by $\mathrm{j}$ 's industries

HCij (Lab), $\quad i, j=C, R C$ - Final consumption of i's regional products, consumed by households mainly dependent from labour income living in region $\mathfrak{j}$

OFD $^{\mathrm{ij}}, \quad i, j=C, R C$ - Other final demand for $\mathrm{i}$ 's regional products, used in region $\mathrm{j}$ $\mathbf{R}^{\mathbf{i}}, \quad i=C, R C$ - Residues on the demand of products in region $\mathrm{i}$ 
HI $^{\mathbf{i}}$ (Lab), $\quad i=C, R C$ - Region i's households income distributed to the households that live mainly from their labour compensations (it includes the mixed income distributed to the self-employed workers)

TPO $^{\mathbf{i}}, \quad i=C, R C$ - Total output of products produced in region $\mathrm{i}$, at basic prices

pii, $i=C, R C-\mathrm{i}$ 's regional products, according to their production industry (generic element of the i's supply table)

TIO $^{i}, \quad i=C, R C$ - Region i's total industry output, at basic prices

$\mathbf{T}(\mathbf{g})^{\mathbf{i}}, \quad i=C, R C ; g=I C, H C, O F D$ - Taxes less subsidies on products, falling upon $\mathrm{g}$, in region $\mathrm{i}$

TT - Total taxes less subsidies on products

$\mathbf{M}(\mathbf{g})^{\mathbf{i}}, \quad i=C, R C ; g=I C, H C, O F D$ - International imports destined to use $\mathrm{g}$, in region $i$

TM - Total International Imports

TIC ${ }^{\mathbf{i}}, \quad i=C, R C$ - Total intermediate consumption by industries, in region $\mathrm{i}$, at purchaser's prices

THC (Lab) , $i=C, R C$ - Total region i's consumption by households mainly dependent on labour income, at purchaser's prices

THI (Lab) , $\quad i=C, R C$ - Total region i's households income distributed to the households that live mainly from their labour earnings

OFD $^{\mathbf{i}}, \quad i=C, R C$ - Other final demand in region $\mathrm{i}$, at purchaser's prices

TIC + TFD - Total intermediate and final demand, at purchaser's prices

NHVA $^{\mathbf{i}}, \quad i=C, R C$ - Gross Value Added which is not directly distributed to households, in region $\mathrm{i}$

TNHVA - Total Gross Value Added which is not directly distributed to households

$\mathbf{S}^{\mathbf{i}}, \quad i=C, R C$ - Savings and net transfers to other institutional sectors of the households that live mainly from their labour income, in region $\mathrm{i}$

TS - Total savings and net transfers to other institutional sectors of the households that live mainly from their labour income

The structure of the model in Table 1 is based on a set of characteristics and hypothesis, which leads to the classification of this modelling approach as a "closed rectangular bi-regional input-output model", using domestic flows at basic prices. Below are presented the key procedures and the main implications regarding (i) the use of domestic flows, expressed at basic prices; (ii) the rectangular model structure, (iii) the regional production technologies and, finally, (iv) the endogenization of households consumption, namely those that live mainly from labour income.

\section{(i) Domestic flows, expressed at basic prices}

The model considers primarily domestic flows (unlike the National Accounts Supply and the Use Tables, from where it is derived (INE, 2012a), which favour an accounting approach at "total flows"). This means that this model focuses on the products of the industries operating within the Portuguese economy, i.e., the rows and the columns for each of the 431 
products include only the products actually produced in Portugal (in $C$ and/or $R C$ ) excluding the internationally imported uses.

The model is at basic prices. Total products output (TPO) and total industries output (TIO) are evaluated at basic prices (nevertheless the industries output (TIO) includes, as usually, intermediate consumption at purchasers' prices - IC); total final demand is also considered at purchasers' prices, although the final demand of each product is consistently considered at basic prices; finally, trade and transport margins are considered as inputs provided by trade services (wholesale, retail or specifically motor vehicles or fuels) or transport services (by different types of freight).

\section{(ii) Rectangular model (industry-technology assumption)}

The model considers 431 products and 134 industries, therefore allowing each industry to produce more than one product, whether they are primary or secondary products (i.e., that are main products of other industries). The rows of matrices $\mathrm{P}^{\mathrm{CC}}$ and $\mathrm{P}^{\mathrm{RCRC}}$ describe the products produced by each industry in $C$ and $R C$, respectively. Regarding primary products, whenever each industry produces more than one product, it is used more specific information from different sources about the actual structure and major dominant products of each industry in $C$ and $R C$. Concerning secondary products, we assume the same weight in total industries production in each of the regions (note that those products represent a non-significant share of the total output).

Rows corresponding to products (431 products $\times 2$ regions) describe their different destinations, which include: the intermediate consumption (IC) in each region (naturally, a product produced in $C$ can be inter-regionally exported and used as intermediate consumption in $R C$ ); the final consumption of the different types of households in both regions; and other destinations in the "Other Final Demand".

Columns corresponding to industries describe their technologies in absolute values, i.e., each product intermediate consumption in each industry, according to the origin's region ( $C$ or $R C$ ); the intermediate inputs internationally imported (although in this case, the total inputs are not disaggregated by products); the (non-deductible) taxes less subsidies 
falling upon the purchased inputs (in order to assure that each industry IC is expressed at purchaser prices); the income generated in each industry and in each region, i.e., the gross value added (GVA), whether it is directly distributed to households living mainly from their labour income, or distributed to some other institutional sector (NHVA).

This rectangular bi-regional input-output model admits that each industry has its own technology, identically to the production of all its primary or secondary products (as explained above secondary products represent only a residual value in total industry production) $)^{4}$.

\section{(iii)Regional production technologies}

Moreover, in general, it is assumed that each industry has the same production technology in both regions, i.e. each input has the same weight in the intermediate consumption regardless the production place.

The equal production technology assumption in both regions is not the most accurate for all the cases, because it does not take into account the disparities of activities within some industries and/or regional differences. E.g., the original information provided by the Portuguese National Accounts Supply and Use Tables (INE, 2012a) considers one column vector of technologies for the electricity industry. However, this industry is composed by different activities such as production and distribution. Further, electricity can be generated by a wide variety of sources, encompassing a set of activities with different production technologies. Thus, as the regions possess different structures of electricity production and distribution there is the need to develop procedures to reflect such regional disparities.

Accordingly, we consider a division of the original electricity industry into 10 different industries. The electricity industry vector of production and intermediate consumption, for the 431 products, provided by the Portuguese National Accounts Supply and Use Tables (INE, 2012a), was

\footnotetext{
${ }^{4}$ See Sargento et al. (2011) for a discussion on the (dis)advantages of rectangular inputoutput models. Deeper descriptions of this kind of structure can be seen in the pioneering contribution of Oosterhaven (1984) and in Miller and Blair (2009: Chapter 5).
} 
taken as the primary data. Then, to disaggregate this vector by the different activities and regions, we proceed to the estimation of each activity's total production and intermediate consumption. The data sources used to estimate such values (for 2010) were: the Portuguese National Statistical Institute (INE, 2015a, 2015b), which supplies information on total electricity production, as well as on total electricity produced by cogeneration plants; the database Quadros de Pessoal, from the Statistical Department of the Ministry of Labour and Social Solidarity (GEP-MTSS, 2011), which provides information on the number of workers in each activity; and the reports published by companies that manage the thermoelectric power plants (EDP Produção, 2011, 2012, 2013; Turbogás/Portugen, 2011; Tejo Energia/Pegop, 2011; EEM, 2008, 2011) to estimate the electricity produced by conventional sources, as well as the energy inputs used in such production; lastly, additional data on the power plants in operation throughout the country was gathered from Pinto and Faria (2015).

The disaggregation of the electricity industry considers one industry of electricity distribution and 9 industries of electricity production according to the following sources: 1) wind; 2) geothermal; 3) hydro; 4) photovoltaic; 5) coal; 6) fuel oil; 7) natural gas; 8) diesel; 9) cogeneration. Each of these sub-industries has its own production technology. The total electricity sector, that merges the 10 sub-industries, produces two distinct products (in each region): produced electricity and distributed electricity. Further, a single column vector of technologies for the refined petroleum industry would hide the regional disparity of its input structure. Indeed, while some regions require more goods and services related to the management activities, others consume mainly inputs directly related to the production process of refined products. Accordingly, we assume diverse production technologies for the different regions, based on Regional Accounts' information (regarding remunerations, Gross Value Added and production of the different regions), taking into account our knowledge of the actual location of the refineries in Portugal. 


\section{(iv) Closed model}

The model considers, both in $C$ and $R C$, different household's types, according to their main source of income, namely: labour earnings, capital income, real estate income, pensions and other social transfers.

The model is "closed" regarding the consumption of households that live mainly from labour income (employees or self-employed workers), i.e., labour income endogenously determines this group's final consumption. The income generated in each region contributes only for the consumption of households living in the same region; commuting and other periodical or seasonal migrations between $C$ and $R C$ (that are negligible between these regions) were not considered. Consumption of other household's types (the non-labour income dependent ones) is considered exogenous, i.e., their consumption expenditures are independent of the generation of productive income (which we do not know how, where and when is distributed to these families), and therefore considered as part of the Other Final Demand.

The Other Final Demand includes the consumption of other household's types (the non-labour income dependent ones), the consumption expenditures of general government and non-profit institutions; the investment (i.e., demand for products used as investment goods, produced in the country, allocated to $C$ or $R C$ according to the place of production), the consumption of non-residents in Portugal that visit both regions and, finally, other international exports of goods and services.

Residential and business rents paid to households are not considered as benefiting those living mainly from labour income, but are instead included in the NHVA vector. Thus, an increase in these incomes does not automatically induce an increase in consumption (as the consumption of the other household's types is deemed to be exogenous).

Finally, it is also important to mention that the portion of Table 1 inside the bold border - a square matrix of dimension 1134 (431 products, 134 industries and 2 extra rows relating to household income, for each one of the two regions) - is the core of the input-output framework implemented. Indeed, one departs from this core to compute the inverse matrix, which comprises a set of multipliers that measure impacts of 
exogenous final demand changes on products and industries production. Also, this inverse matrix includes the impacts on the income of the households that live mainly from their labour earnings, caused by those shocks. Noteworthy, it is also possible to assume exogenous shocks on such income and compute their effects on products/industries outputs. Further, exogenous final demand shocks can be formulated either in terms of products, or by redirecting them to industries.

\subsection{The consumption structure of the different household types}

The multi-sector bi-regional Centro-Rest of the Country input-output model distinguishes among private consumption structures, by different household types, according to their main source of income, namely: (i) labour earnings (wages and mixed income), (ii) capital income, (iii) real estate income, (iv) retirement benefits (pensions) and (v) other social transfers. The technical details on the procedures used to derive the consumption structure for these different household types are briefly mentioned ahead.

The vector of national household's final consumption, for the 431 products, provided by the Portuguese National Accounts Supply and Use Tables (INE, 2012a), is taken as the prime data. Then, we proceed to its disaggregation, firstly by estimating the total households' consumption by each household type, in $C$ and $R C$. The data sources used to estimate such values are: the "Household Budget Survey 2010-2011" (HBS) (INE, $2012 \mathrm{~b}$ ), which provides information on the consumption expenditure per household type; the "Census 2011" (INE, 2012c) for data concerning the number of individuals per region and per household type (in order to reweight the sample of the HBS); and the regional per capita "Local Purchasing Power Index" (INE, 2013), also referring to 2011, to decide upon the total relative consumption between the two regions. Secondly, we estimate the consumption of the 431 products by each household type, in $C$ and $R C$. As the HBS considers data disaggregated only for 200 products, such information is used as a primary data source and then 
to estimate the corresponding disaggregation for the more detailed 431 products level (as considered by the National Accounts), it is assumed that the relative significance of several sub-products is the same in the 2 regions and for all the household types, namely identical to the corresponding shares in the National Accounts.

Accordingly, Table 2 synthesises the estimated consumption structures, by household type (including the different values of the actual residential rents paid by these groups and the consumption of residents outside the Portuguese territory), in $C$ and $R C$. This table refers to resident household's consumption, at purchasers' prices, including also the consumption of internationally imported goods and services. Table 2 considers the aggregation of the 431 products into 10 groups of products.

Table 2: Consumption structure by household type (\%)

\begin{tabular}{|c|c|c|c|c|c|c|c|c|}
\hline Region & \multicolumn{4}{|c|}{ Centro (C) } & \multicolumn{4}{|c|}{ Rest of the Country (RC) } \\
\hline $\begin{array}{l}\text { Household's main } \\
\text { source of income } \\
\text { Products }\end{array}$ & Wages & $\begin{array}{l}\text { Capital } \\
\text { \& real } \\
\text { estate } \\
\text { income }\end{array}$ & Pensions & $\begin{array}{l}\text { Other } \\
\text { social } \\
\text { transfers }\end{array}$ & Wages & $\begin{array}{l}\text { Capital } \\
\text { \& real } \\
\text { estate } \\
\text { income }\end{array}$ & Pensions & $\begin{array}{l}\text { Other } \\
\text { social } \\
\text { transfers }\end{array}$ \\
\hline $\begin{array}{l}\text { Agriculture, forestry } \\
\text { and fishing products }\end{array}$ & 3,86 & 3,93 & 6,54 & 4,98 & 3,60 & 3,97 & 6,09 & 4,95 \\
\hline $\begin{array}{l}\text { Food industry } \\
\text { products }\end{array}$ & 15,61 & 13,42 & 20,52 & 25,15 & 17,20 & 13,54 & 20,88 & 24,99 \\
\hline $\begin{array}{l}\text { Other products } \\
\text { of industry and } \\
\text { construction }\end{array}$ & 33,70 & 27,12 & 28,32 & 23,91 & 30,80 & 27,36 & 25,42 & 24,08 \\
\hline $\begin{array}{l}\text { Energy, water supply } \\
\text { and sewerage }\end{array}$ & 4,07 & 3,99 & 6,52 & 5,97 & 3,79 & 4,03 & 5,66 & 5,94 \\
\hline $\begin{array}{l}\text { Accommodation } \\
\text { and food services; } \\
\text { Wholesale and retail } \\
\text { trade, repair of } \\
\text { motor vehicles and } \\
\text { motorcycles }\end{array}$ & 11,37 & 12,89 & 8,47 & 8,68 & 11,80 & 13,00 & 9,06 & 8,63 \\
\hline $\begin{array}{l}\text { Transportation and } \\
\text { storage; information } \\
\text { and communication } \\
\text { products }\end{array}$ & 7,20 & 6,99 & 6,58 & 9,94 & 7,91 & 7,05 & 7,42 & 9,93 \\
\hline $\begin{array}{l}\text { Financial, insurance } \\
\text { and real estate } \\
\text { services }\end{array}$ & 7,63 & 6,23 & 5,21 & 5,08 & 6,71 & 6,29 & 5,82 & 5,05 \\
\hline Other services & 12,92 & 21,40 & 14,06 & 11,22 & 13,56 & 21,26 & 15,55 & 11,11 \\
\hline Housing rents & 1,68 & 1,24 & 1,61 & 4,59 & 2,43 & 1,25 & 2,02 & 4,68 \\
\hline $\begin{array}{l}\text { Resident's } \\
\text { expenditures abroad }\end{array}$ & 1,95 & 2,80 & 2,17 & 0,47 & 2,20 & 2,26 & 2,07 & 0,64 \\
\hline
\end{tabular}


These data confirms the importance of taking into consideration distinct consumption structures of the different households' types, as well of distinguishing it for the $C$ and $R C$ regions. Indeed, firstly, it is possible to identify that the highest proportion of consumption expenditure, for the majority of household types in both regions, concerns to "Other products of industry and construction". Further, in both regions, households mainly depending on income from "Capital and real estate" are leaders in the relative importance of "Other services", "Resident's expenditures abroad" and "Accommodation and food services; Wholesale and retail trade, repair of motor vehicles and motorcycles", while households depending predominantly from "Pensions" and from "Other social transfers" stand out for "Agriculture, forestry and fishing products" and for "Housing rents" and "Food industry products", respectively. Secondly, the products included in the categories "Agriculture, forestry and fishing products" and "Energy, water supply and sewerage" have higher relative values in the $C$ than in the $R C$ region, for the majority of the household types. Conversely, products included in the categories of "Food industry products", "Accommodation and food services; Wholesale and retail trade, repair of motor vehicles and motorcycles", "Transportation and storage; information and communication products" and "Housing rents" stand relatively higher in the families of the $R C$.

Finally, as mentioned in subsection 2.1, there is the need to convert the information in Table 2 from purchasers' prices to basic prices and from "total flows" to "domestic flows". Accordingly, from the matrix at purchasers' prices, and for each product, are successively removed: the Value Added Tax (VAT); other taxes less subsidies; the wholesale and retail margins; and international imports. Basically, the margins are reclassified to the trade and transport industries, being considered as household's consumption of those industries products. Taxes less subsidies are removed from each product and inserted at the bottom part of Table $1\left(\mathrm{~T}(\mathrm{~g})^{\mathrm{i}}\right)$. A similar procedure is used regarding international imports $\left(\mathrm{M}(\mathrm{g})^{\mathrm{i}}\right)$. Further, it is assumed equal propensity to (internationally) import in both regions and for each of the 431 products. 


\subsection{The Centro - Rest of the Country inter-regional trade}

The estimation of inter-regional trade is perhaps the most critical issue in building up regional input-output models. This task is accomplished, in a first approach, by the "residual method" 5 . This method is based on the assumption that if there is more supply (including international imports) than demand (including international exports) of one product in a given region, this product is inter-regionally exported (in net terms) by this region. Thus, all the components of each product's supply and demand are estimated for the region and the difference gives us the interregional net trade. For bi-regional models net flows are symmetrical between the two regions (and, obviously, the export's destination region and the import's origin region are known for each case).

Further, it is critical to have also information on exports and imports gross values (at least regarding the endogenous part of the model) ${ }^{6}$. The approach here implemented firstly estimates gross imports. The method for estimating gross imports is based on a detailed product classification that relies on several hypotheses and the expertise of the MULTI2C team members, namely their effective knowledge of the Portuguese reality. Three different product types (A, B and C) and corresponding assumptions are considered regarding the determination of gross inter-regional imports, as follows:

Type $A$ products, regionally non-tradable. These products have necessarily to be produced in the same region where they are consumed; the inter-regional imports of these products are zero in both regions, as there is no inter-regional trade; the residue between these products supply and demand is not significant in the majority of the products but it may not be

\footnotetext{
5 This is the general methodology adopted in the MULTI2C models. The methodological issues and corresponding procedures are described in Barata et al. (2011), where the aim was to estimate inter-regional gross imports, for single region models (for small Portuguese NUTS III regions, in the interior part of the country), and developed in Ramos et al. (2013) already in a bi-regional model context.

6 This is the well-known crosshauling problem, firstly approached by Robinson and Miller (1988).
} 
exactly 0 (it has a positive value in one region and the symmetric value in the other). These residues are included in the $\mathrm{R}^{\mathrm{i}}$ column of Table 1 .

Type $B$ products, fully internationally and inter-regionally tradable. These products move around the two regions at negligible costs; there is no reason for a local delivering preference; thus, demand is assumed to be satisfied by local supply or by imports from the other region according to the proportion of the regional products output.

Type $C$ products, regionally tradable between specific locations. This "intermediate" category includes mainly products with high transportation costs or with a strong regional preference; they also include some products for which the demand is usually locally manifested, but satisfied by national companies - a significant part of these product's production process takes place in the company's (national or regional) headquarters, often located in $R C$ - we call this the "headquarters effect" -, and this "headquarters" participation on the production process is considered equivalent to an inter-regional export of the headquarter region to its establishment region.

These procedures generate a first estimate of the gross inter-regional trade in both regions. Gross imports depend on the type of product classification, net inter-regional exports are previously known and gross exports are obtained residually. However, contrarily to what is observed in net inter-regional trade, after this, most of the product's gross imports do not match with the gross exports of the same products in the other region. It is therefore essential to consider a final adjustment, consisting on a simultaneous increase of one product's inter-regional exports and imports (respectively XIR and MIR) in one region, combined with a simultaneous reduction of the same product's exports and imports, in the other region, until the interregional trade gross flows are equal (i.e., XIR (i) $=\operatorname{MIR}(\mathrm{j}), i, j=C, R C$ ). The distribution of these two adjustment weights is associated with the product's relative output in both regions.

Table 3 shows the 10 main products (out of P88 aggregation of the 431 original products) regarding gross and net exports from the $C$ region, which can be considered as forming its economic basis. It is important to note that in the cases where export's destination is investment or 
consumption expenditure of the general government or of non-profit institutions (which are not estimated by region of demand, but for the country as a whole) the gross exports do not include inter-regional exports to $R C$. International re-exportation of imported goods is equally excluded as they were not "distributed" through the two regions.

Table 3: Main products (international and inter-regional) exported from Centro region

\begin{tabular}{|c|c|c|c|}
\hline Unit: $10^{6} €(2010)$ & $\begin{array}{l}\text { Gross } \\
\text { exports }\end{array}$ & $\begin{array}{l}\text { share (\%) } \\
\text { of total C } \\
\text { region gross } \\
\text { exports }\end{array}$ & $\begin{array}{l}\text { Net } \\
\text { exports }\end{array}$ \\
\hline Production, distribution and trade of electricity & 2240.91 & 9.2 & 394.52 \\
\hline $\begin{array}{l}\text { Fabricated metal products, except machinery and } \\
\text { equipment }\end{array}$ & 1385.94 & 5.7 & 600.08 \\
\hline Pulp, paper and paperboard (excluding corrugated) & 1245.77 & 5.1 & 997.26 \\
\hline $\begin{array}{l}\text { Agriculture, farming of animals, hunting and related } \\
\text { services }\end{array}$ & 1137.82 & 4.7 & 129.89 \\
\hline Food and beverage services & 1100.52 & 4.5 & 497.50 \\
\hline Freight transport by road and removal services & 1028.43 & 4.2 & 798.08 \\
\hline Plastics products & 805.09 & 3.3 & 414.05 \\
\hline Accessories for motor vehicles & 783.74 & 3.2 & 208.81 \\
\hline $\begin{array}{l}\text { Basic chemicals, fertilizers and nitrogen compounds, } \\
\text { plastics and synthetic rubber in primary forms }\end{array}$ & 777.10 & 3.2 & -419.20 \\
\hline $\begin{array}{l}\text { Refractory ceramic products; Ceramic building materials; } \\
\text { Other porcelain and ceramic products, non-refractory }\end{array}$ & 678.75 & 2.8 & 637.13 \\
\hline$\ldots$ & $\ldots$ & $\ldots$ & $\ldots$ \\
\hline Total Exports from Centro region & 24232.04 & 100.0 & -1189.35 \\
\hline
\end{tabular}

Table 3 data reveals that the three major gross exporting industries in the $C$ region are "Production, distribution and trade of electricity", "Fabricated metal products, except machinery and equipment" and "Pulp, paper and paperboard". However, regarding net exports, only "Pulp, paper and paperboard" remains on the top three and it is relevant to note the role of "Freight transport by road and removal services" and "Refractory ceramic products; Ceramic building materials; Other porcelain and ceramic products, non-refractory" in the $C$ region economic basis. 


\section{The impacts of income (re)distribution in the Centro region of Portugal}

The bi-regional Centro - Rest of the Country input-output model is here considered to assess the impacts, in both regions, resulting from a shift in income's distribution in the $C$ region. More specifically, it is assumed a $5 \%$ reduction in the labour earnings in $C$, with such amount being "relocated" in gross fixed capital formation (GFCF). Naturally, the GFCF increase is not confined to the $C$ region, but it is expected to spread all over the country. This happens because, contrarily to what generally happens with labour income, the application of the capital remuneration is not tied to the place/region where the production occurs and the operating surplus is perceived. Actually, employees generally live in the place/region where they work, but the same may not happen with capital holders as they usually spend their income in investments through different parts of the country, regardless their living place. Further, in this modelling framework what is actually relevant is where the production of the investment goods takes place, which may happen anywhere in the Portuguese territory, or even abroad, and not necessarily at the actual location of the investment.

The results of this modelling exercise indicate that the shift in income's distribution would generate a net expansionist effect on the Portuguese economy. However, concerning Centro region's total production, the model foresees a reduction of approximately 116 million $€(0.2 \%$ of total output at basic prices), which is expected to be balanced by an increase of approximately 1000 million $€$ in the Rest of the Country's total production ( $0.4 \%$ of total output). Table 4 shows how these effects are distributed in the Centro region, emphasising the products whose production would change the most, as a consequence of this shock. 
Table 4: Centro region's products with higher (+ / -)

changes in production

\begin{tabular}{|c|c|c|}
\hline (Year: 2010) & $\begin{array}{c}\text { Absolute } \\
\left(10^{6} €\right)\end{array}$ & $\begin{array}{c}\text { Relative } \\
(\%)\end{array}$ \\
\hline \multicolumn{3}{|l|}{ Higher increases } \\
\hline Development of building projects; Construction of buildings & 44.08 & 2.0 \\
\hline Civil engineering & 38.51 & 2.2 \\
\hline Specialized construction & 24.19 & 2.1 \\
\hline Fabricated metal products, except machinery and equipment & 16.19 & 0.8 \\
\hline Cement, lime and plaster; Articles of concrete, cement and plaster & 11.42 & 1.5 \\
\hline Total change in products whose production increased & 177.26 & 0.8 \\
\hline \multicolumn{3}{|l|}{ Higher reductions } \\
\hline Monetary intermediation & -13.57 & -1.4 \\
\hline Wholesale and retail trade and repair of motor vehicles and motorcycles & -14.13 & -1.6 \\
\hline Food and beverage services & -23.74 & -1.2 \\
\hline Renting of own or leased real estate & -58.75 & -2.4 \\
\hline Retail trade, except of motor vehicles and motorcycles & -61.19 & -1.9 \\
\hline Total change in products whose production decreased & -293.59 & -0.8 \\
\hline Total net change in Centro region's production & -116.33 & -0.2 \\
\hline
\end{tabular}

To analyse Table 4 results it is important to note that the output decrease in Centro region happens because the initial income reduction occurs for Centro region's households that depend mainly from their labour income, and that these households spend most of their money in the region where they live. Additionally, a portion of this income is spent on non-tradable (type $A$ ) products, which have to be produced in the Centro region itself. As expected, the products with higher production increase are those that are (directly or indirectly) linked to investment, while the higher reductions are mainly associated with household's consumption expenditure (that is deemed to depend on labour income). The overall (negative) impact of this shock in the Centro region shows that the (negative) effect on the consumption products' output outweighs the (positive) impact resulting from investment and related goods' output.

Further, it is worth to highlight that the household's saving rate and transfers to other institutional sectors are relatively high, such that only a portion of household's income is applied into consumption expenditures. Contrarily, when household's income is considered to be 
redistributed in benefit of firm's profits, it is assumed that this amount is fully invested, therefore generating a net expansionist effect for the country as a whole.

This scenario may be criticised and considered as extreme. Indeed, we assume that the labour compensations reduction is fully converted into more investment (except for the part corresponding to taxes on products falling upon the investment goods), but actually only a fraction of household's income is available for consumption - e.g., a part of the revenue retained by companies (NHVA) is used in income taxes or in more transfers to other institutional sectors. Accordingly, we have tested the sensitiveness of these modelling results to this assumption, by considering an additional scenario, where only $80 \%$ of the total labour income's reduction in Centro region is compensated by an increase in GFCF. Even under this new milder assumption, the national expansionist impact remained, namely because household's income that is not consumed (so, it is saved or transferred to other sectors) is about $40 \%$, while we assume not to invest $20 \%$ of firm's profits. Further, this new scenario estimates an output decrease in Centro region of about 179 million $€$ ( $0.30 \%$ reduction against the $0.20 \%$ in the initial scenario) strengthening the negative effect on Centro region's production, while the production growth in the Rest of the Country is estimated to be approximately of 711 million $€$ (an increase of $0.27 \%$ comparing with $0.38 \%$ in the initial scenario).

Noteworthy, in general, these scenarios confirm that regions benefit from income distributions that favour workers (because they generally spent their income in the same region), while are negatively affected by income distributions that benefit capital holders (as it is not certain where the increased profits that benefit capital, after the income redistribution, are really invested, and where the corresponding investment goods are produced). These research results are in accordance with those proposed in Ramos et al. (2011), when estimating the impact on employment for different scenarios concerning the distribution of productivity gains among employees and capital owners, in Portuguese depressed peripheral regions. 


\section{Conclusions}

The leading ambition of this paper is to establish the structure of a bi-regional input-output model for the Centro region of Portugal and the Rest of the Country. The characteristics of this modelling framework allow assessing the impacts of a shock occurring in the Centro region, not only on the region itself, but also the spillover effects that leak to the Rest of the Country. These spillovers return then to Centro region in the form of a feedback effect. These leakages and feedbacks are of two kinds: (i) interindustry effects, due to the fact that one region's intermediate consumption demand is often satisfied by supplies from other regions, and (ii) income effects, as this kind of interregional contamination also occurs with household's consumption (namely of those living mainly from labour income). In this modelling approach, the interregional effects are influenced not only by the private consumption structures in each region but also by the relative weight of different household types, according to their main source of income.

The major conclusion is that the shock effects do not confine to the place where they hit. This is why multi-regional models are vital in regional analysis. We cannot assume that all the benefits (or costs) of a regional occurrence are locked into that region. Sometimes major upshots befall somewhere else and they may even come about elsewhere in a different manner.

This research estimates the impact in the Centro region and nationwide of an income distribution shock hitting directly this region only. More specifically we analyse a $5 \%$ redistribution of the income generated in the Centro region, considering a reduction in the income distributed to the households that live mainly from their labour income, and transferring it to the firms, which are supposed to spend it in investment. The results indicate that this shift in income distribution has an expansionist effect in the Portuguese economy, namely because the share of this additional firm's profit invested is higher than the share of household's income that is consumed. However, remarkably, the Centro region should not benefit with this income redistribution towards firms. Actually, the Rest 
of the Country takes the gain, while the Centro holds the burden. The arguments to explain this result include the fact that household's consumption is largely concentrated on the region where those households live (and work), whereas investments are usually spread all over the country. Thus, overall, this analysis claims that regions themselves may benefit from income distributions that favour workers but are negatively affected by income distributions that benefit capital holders.

Acknowledgments: This work has been framed under the Energy for Sustainability Initiative of the University of Coimbra and supported by the R\&D Project EMSURE - Energy and Mobility for Sustainable Regions (CENTRO-07-0224-FEDER-002004).

\section{References}

BARATA, E.; Cruz, L.; Sargento, A.; Ramos, P.; Ferreira, J.-P. (2011) "Deriving Regional InputOutput Matrices to Assess Impacts in Small Portuguese Peripheral Regions", in Cámara, A., Cardenete, M., Medina, A., Monrobel, J. (eds.), Sectores estratégicos para un nuevo modelo económico, IV Jornadas Españolas de Análisis Input-Output, Universidad Rey Juan Carlos, Madrid.

EDP PRODUÇÃO (2011) Environmental Statement 2010 - Sines Thermoelectric Power Plant (Portuguese only), Directorate of Thermal Production - EDP Gestão da Produção de Energia, S. A., Sines, Portugal.

EDP PRODUÇÃO (2012) Environmental Statement 2011 -Ribatejo Thermoelectric Power Plant (Portuguese only), Directorate of Thermal Production - EDP Gestão da Produção de Energia, S. A., Carregado, Portugal.

EDP PRODUÇÃO (2013) Environmental Statement 2012 - Lares Thermoelectric Power Plant (Portuguese only), Directorate of Thermal Production - EDP Gestão da Produção de Energia, S. A., Figueira da Foz, Portugal.

EEM (2008) Vitória Thermoelectric Power Plant (Portuguese only), Empresa de Eletricidade da Madeira, S.A. - Directorate of Production Services, Funchal, Portugal.

EEM (2011) Annual Report 2010, Empresa de Eletricidade da Madeira, Funchal, Portugal.

FERREIRA, J.; Ramos, P.; Cruz, L.; Barata, E. (2014) "Spill-over effects in the Portuguese economy: Lisbon Metropolitan Area vs. Rest of the Country", $22^{\text {nd }}$ International InputOutput Conference, Lisbon, Portugal.

GEP-MTSS (2011) Quadros de Pessoal (Portuguese only), Database of the Office for Strategy and Planning - Ministry of Labour and Social Solidarity.

INE (2012a) Portuguese National Accounts 2010 (Base 2006), Statistics Portugal - National Accounts, Lisbon, Portugal.

INE (2012b) Household Budget Survey - 2010/2011 (Portuguese only), Statistics Portugal, Lisbon, Portugal. 
INE (2012c) Census 2011, Database of the Official Statistics Portal, Statistics Portugal, Lisbon, Portugal.

INE (2013) Study on the Local Purchasing Power 2011, Statistics Portugal, Lisbon, Portugal.

INE (2015a) Gross production of electricity ( $k W h$ ) by Geographic localization (NUTS - 2002) and Type of electricity production, Database of the Official Statistics Portal, Statistics Portugal, Lisbon, Portugal (available at http://www.ine.pt/xportal/xmain?xpid $=I N E \& x p g i d=i n e \_$indicadores\&indOcorrCod $=0002106 \&$ contexto $=b d \& s e l T a b=t a b 2$; accessed in $9 / 1 / 2015)$.

INE (2015a) Electricity production ( $k \mathrm{Wh}$ ) in cogeneration plants by Geographic localization (NUTS - 2002), Database of the Official Statistics Portal, Statistics Portugal, Lisbon, Portugal (available at http://www.ine.pt/xportal/xmain?xpid=INE\&xpgid=ine indicadores\&indOcorrCod $=0002011 \&$ contexto $=b d \& s e l T a b=t a b 2$; accessed in $9 / 1 / 2015$ ).

MILLER, R.; Blair, P. (2009) Input-Output Analysis - Foundations and Extensions, $2^{\text {nd }}$ Ed., Cambridge University Press, Cambridge, UK.

OOSTERHAVEN, J. (1984) "A Family of Square and Rectangular Inter-Regional Input Output Tables and Models", Regional Science and Urban Economics, 14, 565-582.

PINTO, R.; Faria, F. (2015) Power plants in operation (Portuguese only), Wikienergia Electricity Museum/EDP, Lisbon, Portugal (available at http://wikienergia.com/ edp/ index.php?title=Categoria:Centrais_el\%C3\%A9ctricas_em_actividade; accessed in 9/1/2015).

RAMOS, P.; Barata, E.; Pimentel, A. (2013) "Um Modelo Input-Output Bi-Regional LitoralInterior para Portugal: metodologia de construção e alguns resultados sobre a estimativa de comércio inter-regional", in Santos, J., St-Aubyn, M., Lopes, J., Santos, S. (coord.), Livro de Homenagem a João Ferreira do Amaral, Almedina, Coimbra.

RAMOS, P.; Barata, E.; Cruz, L.; Sargento, A. (2014) "An Input-Output Model with ResourcesConstrained Sectors: An Application to the Agri-Food Development Strategy in the Context of a Portuguese Bi-Regional Model”, 61 ${ }^{\text {st }}$ Annual North American Meetings of the Regional Science Association International, Washington D.C., USA..

RAMOS, P.; Castro, E.; Cruz, L. (2011) "Economically Sustainable Demography: Reversing Decline on Portuguese Peripheral Regions", $19^{\text {th }}$ International Input-Output Conference, Alexandria, USA.

ROBINSON, H.; Miller, J. (1988) "Cross-Hauling and Nonsurvey Input-Output Models: Some Lessons from Small Area Timber Economies”, Environment and Planning A, 20, 1523-1530.

SARGENTO, A.; Ramos, P.; Barata, E.; Cruz, L. (2013) "Regional planning insights from a Portuguese bi-regional Input-Output model", International Conference on Economic Modelling - EcoMod2013, Prague.

SARGENTO, A.; Ramos, P.; Hewings, G. (2011) "Input-Output Modelling based on Total-Use Rectangular Tables: Is this a Better Way?" Notas Económicas, 34, 8-34.

TEJO ENERGIA/PEGOP (2011) Environmental Statement 2011 - Pego Thermoelectric Power Plant (Portuguese only), Tejo Energia - Produção e Distribuição de Energia Elétrica, S.A., and PEGOP - Energia Elétrica, S.A., Abrantes, Portugal.

TURBOGÁS/PORTUGEN (2011) Environmental Summary 2010 - Tapada do Outeiro Combined Cycle Power Plant, Turbogás - Produtora Energética S.A. and Portugen - Energia, S.A., Gondomar, Portugal. 
Série Investigação

Imprensa da Universidade de Coimbra

Coimbra University Press

2015

mais

Programa Operacional Regional do Centro

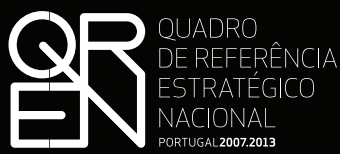

PORTUGAL 2007.2013

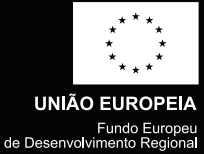

- $\mathbf{U}$

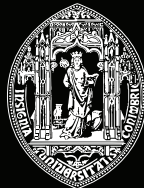

C •

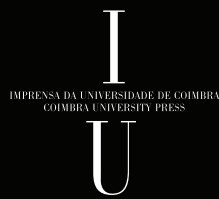

